\title{
UNDERSTANDING INCLUSIVE EDUCATION IN CHILE: AN OVERVIEW OF POLICY AND EDUCATIONAL RESEARCH'
}

Dominique Manghil - María Leonor Conejeros Solarll • Andrea Bustos Ibarrall • Isabel Aranda Godoy'v • Vanessa Vega Córdovav • Kathiuska Diaz Sotovı • TRANSLATED BY Adolfo López Gómez ${ }^{\text {VII }}$

\begin{abstract}
The development of the concept of inclusive education was based on several sources and surrounded by other notions, such as failure, quality and effectiveness, which influence its interpretation and implementation. This article is a theoretical discussion that seeks to understand, from an educational perspective, how this confluence of ideas was formed. To that end, we establish a historical chronology of international policies, national Chilean policies, and research trends, which are understood as universal concerns, work hypotheses and objects of study, respectively. The discussion reveals the complexity of the concept when we contextualize it and when we clarify its logic in psycho-pedagogical terms and in terms of resource effectiveness, quality and inclusion.
\end{abstract}

EDUCATIONAL POLICIES • RESEARCH • INCLUSIVE EDUCATION • QUALITY OF EDUCATION

\section{COMPRENDER LA EDUCACIÓN INCLUSIVA CHILENA: PANORAMA DE POLÍTICAS E INVESTIGACIÓN EDUCATIVA}

\section{Resumen}

El concepto de educación inclusiva se ha construido desde diversas fuentes rodeado de otras nociones como fracaso, calidad y eficacia que influyen en su interpretación e implementación. Este artículo de discusión teórica busca comprender desde una perspectiva educativa cómo se ha construido esta confluencia de ideas. Para esto se realiza una cronología de antecedentes de políticas internacionales y políticas nacionales chilenas, así como de tendencias en investigaciones, entendiéndolas como preocupaciones universales, hipótesis de trabajo y objetos de estudio, respectivamente. La discusión nos revela la complejidad del concepto al mirarlo de manera contextualizada y transparentar las lógicas psicopedagogistas, de eficacia de los recursos y de calidad e inclusión sobre las que se asienta.

\section{POLÍTICA EDUCATIVA • INVESTIGACIÓN • EDUCACIÓN INCLUSIVA • CALIDAD DE LA EDUCACIÓN}

1 This study is sponsored by CONICYT PIA, CIE 160009.

Pontificia Universidad Católica de Valparaíso, Centro de Investigación para la Educación Inclusiva,Valparaíso, Chile; http://orcid.org/0000-0002-0278-9899; dominique.manghi@pucv.cl

II Pontificia Universidad Católica de Valparaíso, Valparaíso, Chile; http://orcid.org/0000-0001-9725-9753; leonor.conejeros@pucv.cl

III Pontificia Universidad Católica de Valparaíso, Valparaíso, Chile; http://orcid.org/0000-0003-0075-0584; andrea.bustos@pucv.cl

IV Pontificia Universidad Católica de Valparaíso, Valparaíso, Chile; http://orcid.org/0000-0001-7178-1690; isabel.arandag@gmail.com

V Pontificia Universidad Católica de Valparaíso, Valparaíso, Chile; http://orcid.org/0000-0003-3333-4798: vanessa.vega@pucv.cl

VI Pontificia Universidad Católica de Valparaíso, Valparaíso, Chile; http://orcid.org/0000-0002-3277-6626 kathiuskads@gmail.com 


\section{PANORAMA DES POLITIQUES PUBLIQUES ET DES RECHERCHES SUR L'ÉDUCATION INCLUSIVE AU CHILI}

\section{Résumé}

Le concept d'éducation inclusive a été construit à partir de diverses sources et entouré de notions, telles que l'échec, la qualité et l'efficacité, qui influencent son interprétation et sa mise en ouvre. Cet article vise à comprendre par le biais d'une discussion theorique comment une telle confluence d'idées s'est produite d'un point de vue éducatif. À cette fin, a été réalisée une retrospective chronologique concernant l'histoire des politiques publiques internationales et des politiques nationales chiliennes, aussi bien que les tendances des recherches dans le domaine, vues comme préoccupations universelles, hypothèses de travail et objets d'étude. Cette discussion a dévoilé la complexité du concept son observation contextualisée, mais a aussi rendu plus transparentes les logiques psychopédagogiques, d'efficacité des ressources, de qualité et d'inclusion sur lesquelles il se base.

POLITIQUE ÉDUCATIVE • RECHERCHE • ÉDUCATION INCLUSIVE • QUALITÉ DE L'ÉDUCATION

\section{PARA COMPREENDER A EDUCAÇÃO INCLUSIVA CHILENA: PANORAMA DE POLITICAS E PESQUISA EDUCATIVA}

\section{Resumo}

O conceito de educação inclusiva foi construído a partir de diversas fontes, cercado de outras noções como fracasso, qualidade e eficácia, que influem em sua interpretação e implementação. Este artigo de discussão teórica tenta compreender a partir de uma perspectiva educativa como foi construída essa confluência de ideias. Para tanto realiza-se uma cronologia de antecedentes de políticas internacionais e nacionais chilenas, bem como de tendências em pesquisas, entendendo-as como preocupações universais, hipóteses de trabalho e objetos de estudo, respectivamente. A discussão nos revela a complexidade do conceito ao observá-lo de maneira contextualizada e torna transparentes as lógicas psicopedagógicas, de eficácia dos recursos e de qualidade e inclusão nas quais se baseia.

POLÍTICAS EDUCACIONAIS • PESQUISA • EDUCAÇÃO INCLUSIVA • QUALIDADE DA EDUCAÇÃO 
NCLUSIVE EDUCATION POSTULATES EMERGED DURING THE LATE 1980'S IN THE ANGLO-SAXON world (OPAZO, 2012) as a movement that advocated radical change in the homogeneous production of the school (GRAHAM; SLEE, 2009). These ideas have been disseminated in a neoliberal context and now they risk being increasingly used as a means to protect the status quo, thus endangering the transformational potential of inclusion for education and for society in general (SLEE, 2013).

Inclusive education as a statement is not instated in vacuum. Within the Chilean current economic and political framework, it does not correspond to its original principles (ALARCÓN; DONOSO, 2017). On the other hand, since the 1990's, policies consider that education is the main driver of social development and a factor of economic integration, since it adds value to production processes based on the knowledge society. In line with the concepts of quality and competitiveness, the focus of Chilean educational policies extends beyond access to encompass the achievement of learning targets. Concretely speaking, given the context of promotion of the free market in Chile and other Latin American countries, new forms of inequity and exclusion have emerged (GENTILI, 2011; PLÁ, 2015).

Furthermore, policy making became concentrated on special education, with financial and normative repercussions concerning the education of children with special educational needs that pointed to a hybrid proposal between integration and exclusion (LÓPEZ et al., 2014). In other words, policies have retained the idea that the individual must adapt to the school environment, 
while also establishing that the school must accept diversity in their community and adapt itself to it (TERIGI, 2009).

In this panorama, the Chilean Inclusion Law 20,845 comes into effect in 2016, and it expresses demands of social movements for a free, quality education (BELLEI; CONTRERAS; VALENZUELA, 2010). However, this law keeps segregation structures in its foundations: a market-based education model as opposed to one based on public values; a logic of business accountability imposed on schools; and an opposition between integration oriented to diagnosis and educational inclusion oriented to legitimizing the other (LÓPEZ et al., 2018). All these features make up a very complex panorama.

Until now, research on inclusive education in Chile is incipient. In general, the subject has been addressed from the perspective of special education (LÓPEZ et al., 2014) or it has been indistinctively based on national or international documents on public policy, as well as on other studies based on academic research (PLÁ, 2015).

In this theoretical discussion, we take into account three sources of influence in order to encompass the phenomenon's complexity (SLEE, 2012): international policies encouraged by organisms such as UNESCO or OECD; national education policies; and the contribution of research that coexists with both types of policy. By conducting a documentary analysis of international organisms, Chilean laws and regulations, and studies and influences from research, we seek to understand the antecedents to consider in order to research about inclusive education in Chile.

Next, the theoretical framework presents the different milestones in the three domains above, which we will analyze from a chronological perspective, from the 1970's onwards. In the first section, we summarize the international policies and the main topics understood here as universal concerns. The second section summarizes the national policies that can help understanding inclusion today at the national level, such policies being conceptualized as working hypotheses. In the third section, we present a few specific objects of study and theoretical constructs suggested by research on educational topics. In the fourth section, we provide a cross-sectional analysis that proposes combining the various milestones in the three influences sources mentioned above, understanding their contribution to the current phenomenon of Chilean inclusive education, and describing the logics about the responsibilities in education.

\section{INTERNATIONAL POLICIES AND UNIVERSAL CONCERNS}

International policies have become fundamental guidelines in terms of universal education as they propose to organize the preferences and goals of the different political actors.

International organizations such as UNESCO, UNICEF, OECD and the World Bank, among others, have guided the design and evaluation of education policies in Latin America. This has enabled explicit, global discussion about educational issues, while implicitly retaining without questioning the implementation of 
the free market model (DÁVILA; NAYA, 2011), which provides a framework for current education. Below we review the main documents which have a politicaleducational purpose.

Broadly speaking, the Declaration of Human Rights works as a framework for the series of conventions signed by various countries during the twentieth century, in a post-war context in which nations sought to recover the dignity of and respect for human beings. Before the 1970's, the universal concerns focused on compliance with human rights and fundamental freedoms with no differences or restrictions. Later, the universal emphasis was on gender differences, while in the 1980's concerns focused on the protection of children's rights.

It was not until the 1990's that an overturn took place in the educational arena towards universal education, in an effort that focused on people that had been excluded and on an education that ensures social inclusion. In that decade, two documents stand out, namely, the "World declaration on Education for All" (UNESCO, 1990) and the "Salamanca Statement" (UNESCO, 1994). The former proposes universal access to education and begins to use concepts such as equity and quality. Learning becomes a central issue, as well as the improvement of learning environments, based on predominant best practices (UNESCO, 1990). The latter alludes to two principles: standardization and integration. Standardization states that everyone has to be educated using resources that are culturally normative so as to allow one's living conditions to be as good as those of the average citizen; in turn, the integration principle focuses on educational measures so that everyone be provided with education and with opportunities to actively participate in it (GODOY; MEZA; SALAZAR, 2004). This statement includes the concept of "special educational needs" in order to ensure education for every child (UNESCO, 1994). This translated into the idea that everyone should be provided with education within a common educational system, with a view to national curriculums.

Next, in the context of the information economy, the UNESCO report (DELORS, 1996) proposes to emphasize a lifelong educational experience, and it distinguishes four pillars that have influenced our curricular documents until today: learning to know, learning to do, learning to live together and learning to be. This document also declares that "education is crucial for the economic development and the reduction of poverty" (1996, p. 1), and it assumes an approach founded on globalization, which sought to make countries interdependent, thus making conflicts and problems universal.

Starting with this way of making education a central issue, since the 2000's, international educational policy documents have been promoting schooling with a twofold purpose: as a means for everyone to achieve their full development and as a way to understand the school as a space of diversity, as a source of enrichment (UNESCO, 2000, 2003).

In that decade, other voices are heard, now from economics, that also proposed roles for education and the school. The OECD 2004 diagnosis reviewed the Chilean national educational policies and recognized that they covered the whole country and provided compensatory programs in underperforming 
schools; the diagnosis also insisted on the necessary resources to improve learning performance in order to improve equity (OECD, 2004).

The notion of inclusion emerges in international policies. First, in 2006, the concept of inclusion is employed in association to a group of people who are internationally recognized as being in a condition of exclusion: the handicapped. The "Convention on the Rights of Persons with Disabilities" (UNESCO, 2006) reaffirms topics such as universal education, equal opportunities and social participation, and points out the importance of guaranteeing an inclusive educational system at all levels, a system where people with disabilities cannot be excluded.

Then, in 2007, inclusion was recognized as a central subject, now with regard to education. In the document titled "Social Cohesion: Inclusion and a Sense of Belonging in Latin America and the Caribbean" (CEPAL, 2007), inclusion is proposed in broad terms, not concerning any group in particular, though expressed in terms of education for all, especially for those living under inequality. Thus, inclusion is primarily conceived to benefit people with intellectual disability and then people with disabilities in general.

At the turn of the decade, economic organizations' proposals grow stronger in defining education as key to overcome social inequality. On the one hand, The World Bank (2011) in its document "Learning for All", focuses on the concept of accelerated learning. To that end, it proposes to increase investments in development, i.e., it offers funds for education to countries in exchange for better academic achievement on the part of these countries. On the other hand, in 2012, the OECD, in its document "Equity and Quality in Education: Supporting Disadvantaged Students and Schools" places the concept of equity at the heart of its argument. Equity comprises two aspects: fairness, i.e., an education that does not discriminate students according to their characteristics; and inclusion, redefined here as basic learning standards (OECD, 2012). The basic argument is that adults without skills are more expensive to society, therefore, education can ensure a good living standard for adults, thus helping nations' economies.

In 2015, we highlight two documents that are mutually complementary. On the one hand, the World Bank stresses that education quality is mainly dependent on the quality of teachers. Burns and Luque (2015) also emphasize the importance of these key actors for improving living standards and the educational system, and they point out that teachers should be concerned with how they use time, materials, technological elements and pedagogical practices. Further, the United Nations Development Program, in its agenda for 2030, puts forward 17 Objectives of Sustainable Development (OSD) to be globally worked on for fifteen years. The Agenda acknowledges the role of education in one of its objectives (OSD 4) and adopts the proposals of the "Incheon Declaration: Towards an inclusive education, equitable and of good quality and a lifelong learning for all" (UNESCO, 2015). This shifts the focus which for the two previous decades had been on education, school and teachers to a wider vision, centered on the new universal concern: sustainable development. The Incheon document provides an actionable framework that emphasizes the transformation of life by means 
of an education where children, youths and adults are educated with the same opportunities - in other words, it proposes to "guarantee an inclusive education, equitable and of quality, and to promote permanent learning opportunities for all” (UNESCO, 2015, p. 70), thus resuming economic organizations' idea of learning goals and accountability for academic achievement.

\section{NATIONAL POLICIES: WORKING HIPOTHESES TO TRANSFORM SOCIETY}

Thinking about a national education policy implies considering it not only as an act performed by authorities, but rather as a complex and plural process with multiple actors involved. Educational policies are here understood as working hypotheses for interventions in the educational field. Such interventions take place as a function of what the causes of problems are believed to be, according to the available perspectives and diagnoses, as well as the prevailing 'rules of the game' in a given society at a given moment in history (BETANCUR; MANCEBO, 2012).

Latin American educational systems have developed different types of strategies or hypotheses with which they promote interventions of different kinds in the public educational system, in response to diagnosis and proposals by international organizations, without questioning the educational system itself (AGUERRONDO, 2008). The interventions generated by public policies build an educational system that is based on previous working hypotheses, with the implication that inclusion as a demand from international policies is not installed in vacuum, but on the foundations and effects of previous policies that have to connect with the policies and regulations in force. Thus, in order to understand inclusion from the perspective public policies in Chile's current context, it is necessary to review the educational ideas driven by such policies. Below we present a selection of those educational ideas that we consider most relevant for the goals of our study from 1970 until today.

At the beginning of the 1970's, a working hypothesis is developed which views the protection of children and social equity from the perspective of social reparation (PARDO; ADLERSTEIN, 2015). This is reflected on the enactment of Law 17.301/70, which created the Corporación Junta Nacional de Jardines Infantiles, which provides institutional mechanisms that improve the living standards of the population (ROJAS FLORES, 2010), particularly poor women and children. This working hypothesis about childhood is kept by the Escuela Nacional Unificada (ENU) under Allende's socialist administration (1970-1973) in order to compensate for social inequality by means of free schooling, student assistance, curriculum planning, and by integrating the school into the community. Thus, quality was being sought through a universal curriculum (OLIVA, 2010).

This project was discontinued by the military coup of September 1973. The subsequent stage (1973-1989) corresponds to the military regime, which may be subdivided into two periods. During the first period (1973-1979), the Ministry of Education was subordinated to the Ministry of the Interior. This meant taking apart the educational structure and eliminating professional and educational 
associations. In the second period (1980-1989), the Ministry of Education was linked to the Ministry of Finance, which focused on privatizing the educational system and reduced funds for education from $7.5 \%$ to $2.6 \%$ of the gross national product (MORENO-DOÑA; GAMBOA, 2014).

For this period, we highlight two working hypotheses: the fostering of specialist professional strategies to avoid school failure, also denominated psycho-pedagogic practices, a hypothesis that is shared with other Latin American countries, according to Aguerrondo (2008); and academic freedom aimed at decentralizing public schools, a Chilean hypothesis framed within the free market model developed by the country (MORENO-DOÑA, GAMBOA, 2014).

With regard to the first working hypothesis, in 1974 the Ministry of Education received a diagnosis reporting on dropout and grade repetition figures (GODOY et al., 2004) as the cause of school failure. Based on this, committees were formed to design interventions that aimed to avoid school failure by using professional strategies (CAICEO, 2010).

Firstly, in terms of special education, study programs and educational spaces were implemented for populations with special needs (mentally or visually impaired people; those with specific language or math learning disabilities; people with oral or hearing disorders), and in 1977 (through Decree 911) individualized attention to students is encouraged, which in turn fosters the creation of special primary and secondary schools that include specialist personnel.

Secondly, in terms of primary and secondary regular schools, differentiated educators were hired to teach students with special needs who were at risk of repeating or dropping out of school, thus creating differentiated groups (GODOY et al., 2004). Finally, in terms of professionals in spaces outside the school, the centers for psycho-pedagogic practices were created in 1975 (CAICEO, 2010). According to the hypothesis of psycho-pedagogical practices of Aguerrondo (2008), all of these decisions assume that the problem lies in the individuals who generate school failure, and solutions for this national problem are sought via special education.

With regard to the second working hypothesis, during this period: in order to install freedom of teaching to decentralize public schools, policies were implemented in the 1980's which aimed at decentralizing and privatizing the management of state-funded schools. The goal of these policies was to improve the efficient use of funds by introducing the neo-liberal model in education (INZUNZA, 2015). The force driving the changes was the Constitution from 1980, which explicitly contains the concept of freedom of teaching (MORENO-DOÑA; GAMBOA, 2014). It transfers the responsibility of the State in terms of educational potential from its status of common good into that of a consumption good that is subject to the policies of supply and demand. To this day, this translates into education being provided with different levels of quality, since those who can afford it get to choose and access higher quality education, while those who cannot afford it have public education (until 2017, run by municipalities) of lower quality (ALARCÓN; DONOSO, 2017).

Municipality-run education and shared funding as a working hypothesis reveal that school failure is not only due to individual failure, but also to 
homogeneous management practices, a first step towards privatization (OLIVA, 2010) and to considering education as a market good (NEF, 2002).

This logic is expressed in the Constitutional Organic Law on Education (LOCE), which was enacted at the end of the military regime as one of the "tying laws". It became a guiding principle for subsequent years in terms of education: education levels, the subsidiarity principle and the State's duty to guarantee basic educational contents (Law 18.962, 1990). From then on, the State transferred its administrative responsibility to each municipality and to private funding agencies; the Ministry of Education's responsibility becomes limited to managing curricular topics and ensuring student attendance (OLIVA, 2010). Underneath what was perceived as decentralization, privatization reinforced social segregation, while exempting the State (ALARCÓN; DONOSO, 2017).

During the 1990's, the Aylwin and Frei administrations kept the working hypothesis of the previous period, and focused on providing opportunities to people at social risk and to those living in poor areas. Their policy involved: adjustments to subsidies, a regulatory framework for teachers, longer school hours (JEC), updating the school curriculum, launching the Educational Quality Measuring System (SIMCE), improving educational institutions' infrastructure, including people with disabilities into general education environments (Decree 1/1998), and technical support for teachers. During that decade, the country's educational architecture was never revoked or questioned, which consolidated both the process of making education a municipality-run service and the shared funding model and mechanisms (MORENO-DOÑA; GAMBOA, 2014).

Finally, the last period spans from 2000-2019, comprising the Lagos, Bachelet and Piñera administrations, with the last two of them serving second terms. The public policies kept the previous working hypotheses, with a focus on enhancing pre-school, primary, secondary and tertiary education through various projects, programs, laws and decrees aimed at improving teachers' working conditions and training, as well as improving reading, writing and mathematics skills, the curriculum, among others. During the Lagos administration, a series of programs stand out, such as the Network of Teacher Trainers, High School for All, LEM (a language and mathematics program) and English Opens Doors; it also established compulsory and free secondary education (Law 19.876) and initiated the assessment of teachers, as well as a policy of sanctions to teachers (Law 19.961) as part of the mechanisms based on competition and accountability.

In 2006, as Bachelet took office, the society's demands regarding education increased, and secondary education students mobilized to demand the revocation of the LOCE. The government responded by announcing improvements in the quality and access to education through legislation such as: 1) Law 20.248, known as the SEP Law (School Preferential Subsidy), which benefited students from low income families ("priority students") by using extra funds to hire support teachers and pay for technical assistance; 2) Law 20.370/12009, the General Law for Education, which revoked the LOCE, thus changing the conditions for primary and secondary education, while keeping the same conditions for higher education; 3) Decree 170, which sets the rules to determine which students have 
Special Educational Needs and are eligible for a subsidy increase; 4) the program Chile Grows With You, which focused on children under 4 years old, among others.

In 2010, during the Piñera administration, Law 20.710 was enacted which established mandatory and free early childhood education for children aged 2-3 years; in addition, it increased by $21 \%$ the subsidy for schools while keeping the criteria of attendance (also known as voucher criteria). Laws 20.422 and 20.822 were enacted, the former with the purpose of promoting the social inclusion of people with disabilities, and the latter aimed at compensating retired teachers via a bonus whose allocation was based on pedagogic excellence. Other programs include the System of Quality Assurance in Education (Quality Agency), the Bicentennial High School and the Safe School Program. In 2015, Decree 83 was issued focusing on flexible curriculum, and in 2016, Law 20.835 was enacted which created the Undersecretariat for Pre-School Education.

In this context, Law 20.845 for School Inclusion was enacted (2016) which responded to the demands of citizens' movements from 2011 onwards and established that schools receiving government subsidy are not allowed to select student admissions, cannot profit using government money and must be free. All this aims at structural changes in the educational system, while keeping the market-oriented ideology: parents can choose where their children are to be educated (ALARCÓN; DONOSO, 2017). Thus, inclusion is defined in a way that differs from international policies, with a public education that is segregated under social inequity and which competes with privatization and freedom to teach - therefore, a public education that is hardly able to instate a system that can offer an equal level of participation to every student.

\section{RESEARCH OBJECTS AND THEIR THEORETICAL CONSTRUCTS}

Research in general, and research of education in particular, reveals oppositions between different forms of knowledge and of the production of meanings, all of which are of a political nature (SLEE; ALLAN, 2001). Nowadays, in order to understand education, it is necessary to study an object and produce science-based arguments.

In this section, as in the previous ones, we look at the last four decades with regard to the broad topics of education research. To that end, we will examine the construction of objects of study that bear a dialectic relationship with political proposals on education so as to construct and at the same time reflect on them.

By looking into the academic and research context of the 1960's, we can see that didactics started to seek bases for the scientific foundations of teaching by resorting to Psychology (COLL et al., 1999). Up until the 1970's the conductivist schools predominated (BRAVO, 2009). The cognitivist paradigm emerged in Chile during the 1970's.

In 1974, the results of a Chilean study titled "Elementary school failure and its consequences on education, health and the economy" became public (BRAVO, 2009). This study built on behaviorism to propose an explanation based 
on the mental processes of students, and pointed out that many students were repeating grades or dropping out of school early on because they did not learn how to read or calculate (ESCUDERO, 2005).

This report raised debates in Chile about the idea of school failure, a concept that - according to the theoretical influences of the period - used to hold every individual responsible for the success or failure of the school system. Along with this, issues like dyslexic children and slow learners started to be discussed, and solutions began to be sought for educational problems that originated in the children themselves. This caused the focus of explanations to shift from school learning based on operant conditioning to mental processes with an emphasis on psycho-linguistic processes in order to explain learning difficulties (BRAVO, 2009).

According to Abbeduto, Evans and Dolan (2001), this trend reflects the influence of psychological and linguistic theories that explain cognitive processes as universal in idealized individuals. These theories subsume the differences between people to common general traits, which produces social effects such as the use of standardized tests, the early use of intelligence tests, as well as remedial education (FERNÁNDEZ; ALCARAZ; SOLA, 2017). From this point on, the "atypical" development is dealt with by pathologizing situations that are inherent in daily life, thus moving them into the medical field, which may define them as disorders, mental problems to be addressed by using medications and professional treatment (RIBEIRO, 2015), which attributes deviations from the artificial norms to children who are from different social, cultural or ethnic origin.

Research based on these assumptions is focused on explaining student failure in school programs by resorting to individual alterations in their own cognitive processes, while underscoring the outcomes of experimental interventions focused on the individual and the origin of its shortcomings (VELLUTINO et al., 2004).

Along with this perspective, during the same decade two ideas influenced by sociology grew stronger and sought alternative visions: the conceptualization of literacy as a means to reverse social exclusion, with the emblematic contribution of Paulo Freire (PLÁ, 2015); and the ideas of pedagogical knowledge and pedagogical practices about teacher empowerment, based on the Colombian pedagogical school influenced by Zuluaga (RÍOS, 2012), from a Foucaultian perspective.

In the 1980's in Chile, there is an increase in the number of studies explaining the misalignment between the mental processes that an individual must mobilize to master the learning required in the school setting (BRAVO, 2009). Ideas on equity and educational inclusion from a social perspective start to be proposed in the region by researchers such as Juan Carlos Tedesco, Pablo Latapí, Cecilia Braslavsky, y Ernesto Schiefelbein (PLÁ, 2015).

Research published during this period report high repeat and dropout rates in the education systems in Latin America in the 1980's. In Chile, 24.3\% of children had repeated at least one course (HIMMEL et al., 1984). As a consequence, in the late 1980's there is abundant literature discussing education quality, a concept about which there is no consensus, which makes it ambiguous and 
confusing (ROMAN, 2013) and forces an ideological ascription focused on a single national curriculum to be accomplished.

In the nineties, we can see that the object of research shifted from the individual's responsibility for failure to the school's responsibility as an institution; emphasis then starts to be placed on efficacy, i.e., the system's academic success is the responsibility of the school and teachers, who must meet predefined targets. During this period, studies such as that of Cardemil et al. (1991) about factors affecting learning improvements, point out that the quality of the school has a greater weight in determining student performance than family factors in a poverty context. So, the most important factors, according to this line of thought, are: organization and management; teachers and pedagogical processes. This, in turn, leads to research on topics such as: expectations on academic achievement, mastery of content and methodology, continuing education, a collaborative work environment, scheduling, and instructions on teaching how to learn, among others.

In this context, where the school by itself has to be efficient in the face of the problem of children who do not learn the curriculum, evidence on student achievement is to be collected from national standardized measurements of learning quality, such as the SIMCE test on different areas of knowledge and at different school levels. The object of study is the quality of the product shaped by the educational system (ALARCÓN; DONOSO, 2017) based on factors associated to faculty's efficiency level (CARDEMIL et al., 1991). For example, Arancibia and Álvarez (1994) conclude that one way of improving education quality is to optimize teachers' performance in the classroom, which, according to them, relies on the process of identifying good and bad practices based on teachers' qualities, as well as on evaluations and incentives that will determine the distinctive abilities of a good teacher.

At the turn of the century, the objects of research encompass both the 2004 OECD report (SOTOMAYOR; DUPRIEZ, 2007) and social movements. In 2006, the so-called "penguin movement" of secondary education students crudely revealed the injustice about the public education they were getting and demanded a transformation in the education system. Research provided input for policy making by suggesting that the foundations of the intended educational reform should be reviewed in order to ensure student learning. To that end, three topics were put on the table: "teachers' ability to teach; managers and management teams' ability to run primary and secondary schools; and the resources at their disposal” (BELLEI; CONTRERAS; VALENZUELA, 2008, p. 15).

Thus, research during the first decade of this century, based on unchallenged assumptions about the information society and the knowledge economy, underscored teachers' individual responsibility and the notion that school failure was the result of using inappropriate didactics and pedagogy, which would require a more refined control process (FONTAINE; EYZAGUIRRE, 2001). An effective teacher was thus defined as someone who is able to provide evidence that his/her students have indeed acquired the appropriate knowledge and skills, which makes learning akin to acquisition, and efficacy to the national 
assessment indicators. In turn, studies about school leadership grew to recognize that management teams were a determinant factor in meeting the quality goals, both in terms of teaching and learning and in terms of transforming the school community (LEIVA; ASTORGA, 2014).

Unlike the Chilean research context, in Anglo-Saxon research, criticism stared to emerge as early as in the 1980's with regard to the unexpected effects of psycho-pedagogic practices and the pathological model used in education (OPAZO, 2012). On the one hand, this criticism targeted the sophisticated student classification mechanisms and detailed diagnosis about the variety of handicaps or impediments to school learning (GRAHAM; JAHNUKAINEN, 2011). On the other hand, it was directed against the channeling of government funds, materials, and technical resources into such classifications and diagnoses based on medical evidence (SLEE, 2012; LÓPEZ et al., 2014). Based on this debate from abroad, the first conceptualizations that came close to an inclusive education emerge as an effort to move away from the model that views the student as a failure.

In this empirical-ideological context of failure and effectiveness, in 2015 the idea of inclusive school becomes established in Chile; it had been promoted by international policies, and becomes a national policy through the Law of School Inclusion, thus challenging research of the Chilean school that excludes, such exclusion being understood in a number of ways. In recent years, some Chilean studies have challenged the ability of public policies to materialize their discourses according to which teachers are to engage in managing the vulnerable other, rather than dealing with difference (INFANTE; MATUS; VIZCARRA, 2011). Those policies have also highlighted the difference between inclusive education and social inclusion, the former being an instrument of social justice and cohesion surrounded by the words diversity and quality, while the latter is defined as a function of differences, identities, and democratic communities (ARMIJOCABRERA, 2018). Others have contributed to exposing the social, political and economic context in which inclusion takes place (SISTO, 2019; LÓPEZ et al., 2018). All the above can help us progress towards a critical and context-sensitive view of research that rightfully questions the idea of a school that excludes.

\section{PUTTING THINGS IN THEIR RIGHT PLACE}

After this summary of international policies, national policies and research concerning education in recent decades, we now turn our focus to a temporal convergence, in order to delve into the influences that allow understanding inclusion in a particular way. Figure 1 summarizes the milestones and the evolution of the central concepts discussed in this section.

The diagram organizes four elements: 1 ) at the top, the concepts that installed the international policies as universal concerns; 2) at the center, the chronology of some of the legal milestones in the policies of our country which make them distinctive; 3 ) at the bottom, the main objects of study of educational research regarding the discussion about inclusion; and 4) the overlapping ovals illustrate the logics that construct the entity responsible for the success or failure 
of education in Chile. These overlapping figures are used here to indicate that the current logic is not formed in vacuum, but includes the two prior logics, which allows understanding inclusion and quality in our country in a particular way. Subsequently, we elaborate on the logics we identified in order to organize the interpretative analysis of the inputs from the three previous sections. Here, our goal is to debate about the universal concerns and the objects of study of research agendas as a function of how national policies are implemented as working hypotheses and how they pervade social practices about education.

\section{FIGURE 1}

RELATIONSHIP BETWEEN ELEMENTS OF INTERNATIONAL POLICIES, CHILEAN DOMESTIC POLICIES, AND EDUCATION RESEARCH OBJECTS IN RECENT DECADES

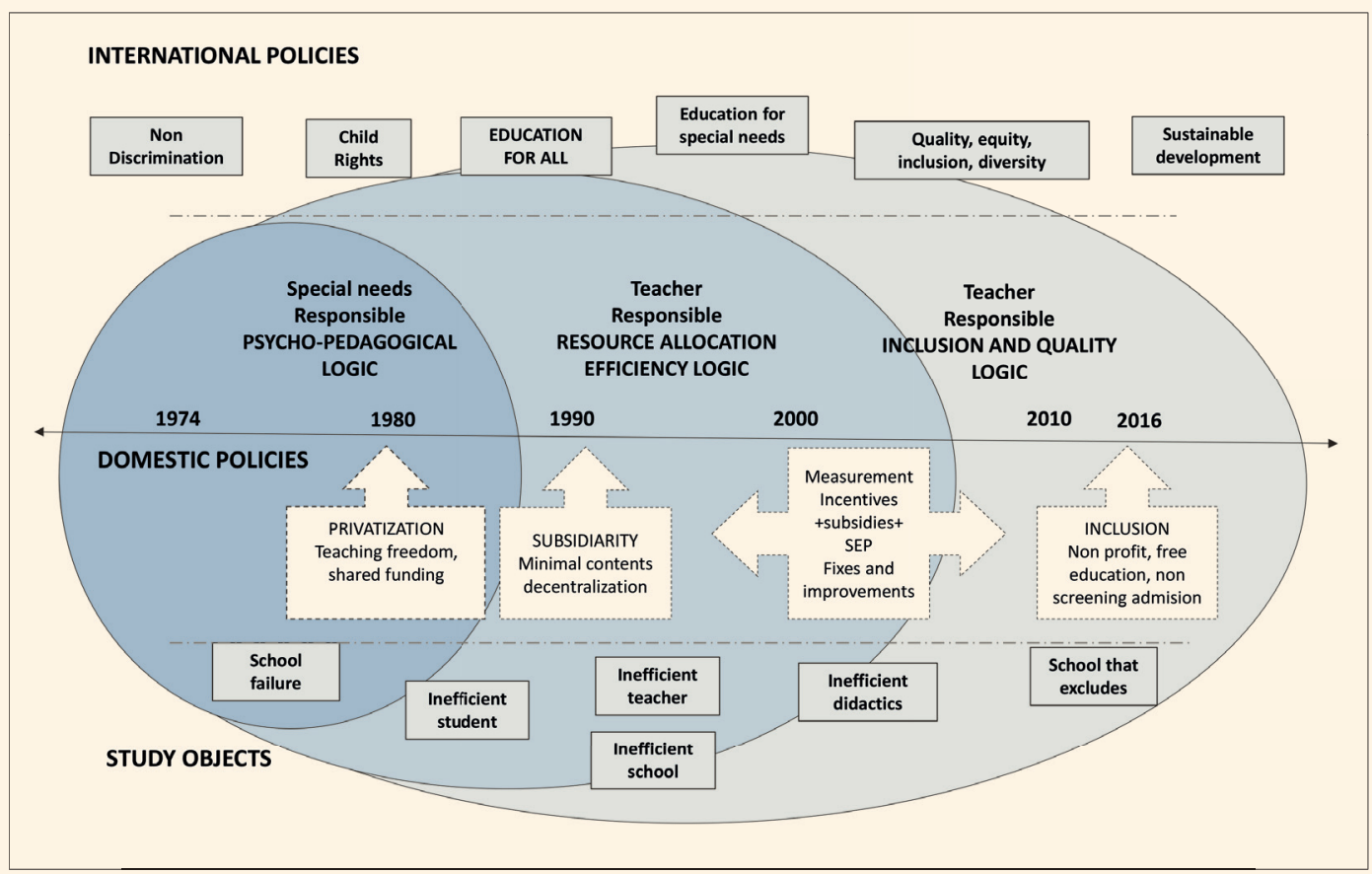

Source: Designed by the authors.

The first logic about the responsibility of education is a psycho-pedagogical one. The previous sections provide a context about the educational emphases during the 1970's. A first milestone to be highlighted took place following the coup d'état in Chile, when domestic research had an impact on public policy (CAICEO, 2010). The 1974 Chilean study diagnosed the Chilean education as a school failure, providing evidence of high repeat and dropout figures. Because that study was informed by the newborn cognitive paradigm, it provided answers about the causes of such failure: the children who repeated grades or dropped out of school had learning problems stemming from mental processes that deviated from the norm. Thus, the cause was dealt with according to a psychopedagogical logic (AGUERRONDO, 2008). The authorities passed laws to engage other professionals, such as teachers specializing in children with special needs, psychologists to help students by using detection, diagnosis and referral, and individual intervention in students' learning processes (BRAVO, 2009). These 
decisions were meant to normalize students and were operationalized by means of centers for diagnosis, schools for students with special needs, the formation of special needs groups, among others (CAICEO, 2010).

Thus, the student is viewed as inefficient and the cause of school failure, and the constructs of disorders and learning impairments promote a pathological model of the individual. These views were reinforced by research and implemented in schools based on the regulations during the 1980's. Such regulations made it possible to use individualized clinical interventions with little connection with teachers and with focus on specialist work that was supposed to improve the individual with regard to his/her difficulties (TERIGI, 2009). In the late 1980's, research focused on psycho-pedagogical topics such as the individual's short term verbal memory or phonological recognition, under the assumption that such an intervention would make it easier to decode meanings and contribute to acquiring skills such as reading comprehension (BRAVO, 2009).

At the same time as the centers for diagnosis and schools started to operate with groups with special needs, domestic policies born the mark of privatization along with the principle of freedom of teaching, which materialized in the process of making education municipality-based and in the possibility of funding private education with public funds. With the 1980 Constitution, a transformation started to take place in education under the aegis of a free market economy, which induced unanticipated forms of inequity and educational exclusion (GENTILI, 2011; PLÁ, 2015). The legislation made it possible to educate children in different ways depending on the family's financial status (ALARCÓN; DONOSO, 2017).

In the 1990's, an important misalignment could be seen between worldwide concerns and the reality in our country. On the one hand, international policies propose the idea of education for all, with a focus on expanding access to education (PLÁ, 2015) as a means to solve poverty and social inequity problems. On the other hand, in Chile, the end of dictatorship, along with the existence of tying policies such as the LOCE, materialized the subsidiary role of the State in terms of education, as well as a curriculum that emphasizes contents. A contrast can be seen here between different levels of analysis: at the international level, attention is focused on education in dealing with the problems of unfair societies, while in Chile, education remains in the hands of financial supporters, with an emphasis on the financial and managerial aspects of the educational resources.

The object of research is broadened to encompass the student-centered notion of failure and directed towards attributing the responsibility to teachers and to the school as an institution. Effectiveness emerges as a theoretical construct, thus building the second logic under which resources are expected to be allocated with effectiveness, and the responsibility for the success of the social system rests on the abilities of teachers and the school to meet targets.

Thus, the second logic of resource effectiveness educates a student who must prove his/her learning skills and learn the curriculum. These learning skills 
are measured and evidence about the performance of each school is obtained based on the SIMCE scores for different knowledge areas school levels.

In the first decade of the twenty-first century, international organizations and research in the field converge in attributing to teachers the individual responsibility, thus redefining the notion of school failure as a result of the use of inappropriate didactics and pedagogy (FONTAINE; EYZAGUIRRE, 2001). Economics-oriented entities such as the OECD and the World Bank become validated as legitimate voices to talk about learning and equity. Domestic policies are synchronized to create a punitive environment in the school context, for example, with the arrival of supervisors of effective financial resourse use (CARRASCO-AGUILAR et al., 2018) who assess teachers, principals and students in terms of allocated resources and expect learning outcomes regardless of the history of public education and domestic educational policies (ALARCÓN; DONOSO, 2017).

The logic of quality and inclusion became established in Chile with the Law of Inclusion, which incorporates the international policies' ideas of rights and nondiscrimination which had been left aside for four decades during which the logic of psycho-pedagogical practices and resource allocation effectiveness transformed the public education system in Chile. The conceptualization of inclusion in Chilean documents of the current decade still corresponds to that of international documents from the 1990's, and becomes established in a public education that has been invaded by management and supervision, besides being consistently marked by segregation and discrimination by the sequence of domestic policies based on the working hypotheses of compensatory actions, but which do not change the basic model (LÓPEZ et al., 2018, ALARCÓN; DONOSO, 2017).

The different political actions and studies collaborate to the social construction that points to teachers' central responsibility for solving the country's inequity issues while concealing the other social conditions necessary to transform a society. Among the decisions that build the idea of pedagogical decentralization are: specialist assistance by external experts as a decontextualized response to inefficient didactical practices (BELLEI; OSSES; VALENZUELA, 2010); the deployment of other professionals in the school in order to deal with the arrival of new populations into the school; and the assessment of teachers. It is socially accepted that a teacher needs to show a good performance score, as emphasized by international organizations, associated to individual indicators defined without taking into account the context of the school space in which he/she teaches, as if that measure alone could guarantee the desired inclusive quality.

The logic of quality and inclusion becomes established over those of effective resource allocation and psycho-pedagogic practices, with public education being especially affected. The working hypotheses of domestic policies that supposedly aim at equal opportunities seem to have made a contribution in the opposite direction. By seeking to compensate for the opposition between individual equality and the social inequities that emerged in the Chilean political and economic context described earlier, these policies end up increasing and legitimizing inequities (SISTO, 2019). In the name of avoiding school failure 
and resource allocation inefficiencies and addressing quality issues and now also inclusion issues, the educational system has generated selection mechanisms based on meritocracy, thus ranking students and teachers in terms of their scores and ultimately building a hierarchical structure for them (ROMAN, 2013). The new object of study, namely the school that excludes, reflects a struggle between winners and losers, with the former being benefited in terms of their successful school trajectory or professional careers, while the latter are blamed for the failure of society and punished for it (DUBET, 2004).

\section{CONCLUSIONS}

The retrospective and analytical view we have attempted to outline as researchers who study inclusive education provides an initial panorama for this endeavor. We are aware that research decisions are ultimately political. For instance, in the face of massive school failure, we as researchers might have been suspicious of the school. Instead, our suspicion was directed to the individuals and, for a long time, failure was interpreted based on a model of individual pathology (TERIGI, 2009).

Inclusive education is not the natural step that follows the discourse of education for students with special needs, but rather a fundamental paradigm change that has not been recognized as such, given the contradictory context in which it becomes established (SLEE; ALLAN, 2001).

Thus, in order to conduct research on inclusion, one should not overlook the complexity of the historical context in which this idea is situated, where the idea of inclusive education coexists with that of social inclusion (ARMIJO-CABRERA, 2018) mixed with deficit and inadequacy to standard curriculum and didactical practices, where the responsibility of individuals and the school as an institution are above a situational analysis that takes into account the community and the connections with other social organizations. On the other hand, it is necessary to recognize research as a field of political struggles between different ways of organizing knowledge and producing meanings (SLEE; ALLAN, 2001). These can influence not only domestic policy making but also the daily practice of those in charge of implementing them, since the working hypotheses end up forming patterns of social interaction which provide possible agendas for social interaction and, at the same time, limit them (CARRASCO-AGUILAR et al., 2018).

The elements of international, domestic and research policies have aligned with the logics of quality and inclusion, and have dragged along the previous ones without modifying the ideological framework (SISTO, 2019), thus legitimizing inequity and social exclusion (PLÁ, 2015), conveniently maintaining the status quo and threatening the transformative power of inclusion both for education and for society in general (SLEE, 2012).

The implementation of this type of logic produces unexpected effects on those concrete contexts where the educational responses to domestic policies are implemented. First, the school culture of classifying students according to their characteristics, paces, styles, behavior, etc., always in contrast with standardized parameters. Therefore, it is common for one to hear about the "special", 
"differential”, "adjusted" student, thus connoting otherness. Secondly, given the competition that predominates in the classroom in a system that aims to meet learning targets rather than educate citizens for society (SLEE, 2012), sometimes students are unable to meet those targets within the same timeframe as their peers. This reinforces the idea of abnormality, since the "normality" of some is understood as a central point around which are those who have learned within the "normal" timeframe, which puts the rest in the outskirts, thus generating a cycle of exclusion (GRAHAM; SLEE, 2009). Thirdly, a technical apparatus is built which includes paperwork, training sessions to diagnose and get funds from the State for children with labels that allow more money to be allocated to the schools. This involves, for example, the emergence of "abnormal" students, but also having people hired to label them, i.e., "abnormalizers" (SKLIAR, 2007). There are also the experts in specific topics who hand out recipes that schools need so that the didactics used by teachers are effective (BELLEI; OSSES; VALENZUELA, 2010), thus creating a category of those who know effectiveness and quality solutions and another category of those ignore such skills - and whose teaching is poor and ineffective. Thus, we have collaborated to the social construction of teachers' essential responsibility for providing solutions for the country's inequity, which conceals the other social conditions that are necessary to succeed in transforming a society.

Therefore, as pointed out by Slee and Allan (2001), inclusion is faced with the challenge of taking a position as a project within the cultural policy of knowledge creation beyond the idea of diversity, a project that can help raise suspicions about political and research stances that justify decisions highly inconsistent with inclusion, and these are necessary intermediate steps to succeed in building an inclusive education and an inclusive society.

\section{REFERENCES} ABBEDUTO, Leonard; EVANS, Julia; DOLAN, Terrence. Theoretical perspectives on language and
communication problems in mental retardation and developmental disabilities. Mental Retardation and
Developmental Disabilities Research Review, v. 7, p. 45-55, Feb. 2001.

AGUERRONDO, Inés. Revisar el modelo: un desafío para lograr la inclusión. Perspectivas: Revista Trimestral de Educación Comparada, Ginebra, v. 38, n. 1, p. 61-80. 2008.

ALARCÓN, Jorge; DONOSO, Sebastián. Hitos significativos de la política educacional del gobierno de la coalición por el cambio. Estudios Pedagógicos, Valdivia, v. 43, n. 1, p. 371-388, 2017. Availabe at: https://scielo. conicyt.cl/scielo.php?script=sci_arttext\&pid=S0718-07052017000100021\&lng=es\&nrm=iso. Access on: June 2018.

ARANCIBIA, Violeta; ÁLVAREZ, María Inés. Características de los profesores efectivos en Chile y su impacto en el rendimiento escolar y autoconcepto académico. Psyke, Santiago, v. 3, n. 2, p. 131-143, 1994.

ARMIJO-CABRERA, Muriel. Deconstruyendo la noción de inclusión: un análisis de investigaciones, políticas y prácticas en educación. Revista Electrónica Educare, San José, v. 22, n. 3, p. 1-26, sept./dic. 2018. Availabe at: https://www.revistas.una.ac.cr/index.php/EDUCARE/article/download/9071/13373/. Access on: Mar. 2019.

BANCO MUNDIAL. Aprendizaje para todos: invertir en los conocimientos y las capacidades de las personas para fomentar el desarrollo. Estrategia de Educación 2020 del Grupo del Banco Mundial. Washington D.C., 2011. Availabe at: http://siteresources.worldbank.org/EDUCATION/Resources/ESSU/4632921269917617150/6915424-1279137061297/ExecSummary_Spanish.pdf . Access on: Mar. 2019. 
BELLEI, Cristián; CONTRERAS, Daniel; VALENZUELA, Juan Pablo (ed.). La agenda pendiente en educación. Santiago: Salesianos, 2008.

BELLEI, Cristián; CONTRERAS, Daniel; VALENZUELA, Juan Pablo. Ecos de la revolución Pingüina. Santiago: Pehuen, 2010.

BELLEI, Cristián; OSSES, Alejandro; VALENZUELA, Juan Pablo. Asistencia técnica educativa: de la intuición a la evidencia. Santiago: Ocholibros, 2010.

BETANCUR, Nicolás; MANCEBO, María Ester. Políticas educativas en tiempos de cambio: actores, programas e instituciones en Uruguay y la región. Revista Uruguaya de Ciencia Política, Montevideo, v. 21, n. 1, p. 7-12, enero/jun. 2012.

BRAVO, Luis. Psicología educacional, psicopedagogía y educación especial. Revista Investigación en Psicología, Lima, v. 12, n. 2, p. 217-225, dic. 2009.

BRUNS, Bárbara; LUQUE, Javier. Profesores excelentes: cómo mejorar el aprendizaje en América Latina y el Caribe. Estados Unidos: Grupo del Banco Mundial, 2015.

CAICEO, Jaime. Esbozo de la educación especial en Chile: 1850-1980. Revista Educación y Pedagogía, Antioquía, v. 22, n. 57, p. 31-49, mayo/agosto 2010.

CARDEMIL, Cecilia; LATORRE, Marcela; FILP, Johanna; GÁLVEZ, Grecia. Factores que inciden en el mejoramiento de los aprendizajes en la educación básica. Estudios Pedagógicos, 1991. Availabe at: http://repositorio.uahurtado.cl/handle/11242/9421. Access on: July 2017.

CARRASCO-AGUILAR, Claudia; ASCORRA, Paula; LÓPEZ, Verónica; ÁLVAREZ, Juan Pablo. Tensiones normativas de los fiscalizadores de la Superintendencia de Educación en la(s) política(s) de convivencia escolar en Chile. Perfiles Educativos, v. 40, n. 159. p. 126-143, marzo 2018.

COLL, César; MARTÍN, Elena; MAURI, Teresa; MIRAS, Mariana; ORNUBIA, Javier; SOLÉ, Isabel; ZABALA, Antoni. El constructivismo en el aula. Barcelona: Graó, 1999.

COMISSÃO ECONÓMICA PARA A AMÉRICA LATINA E CARAÍBAS - CEPAL. Cohesión social: inclusión y sentido de pertenencia en América Latina y el Caribe, 2007. Availabe at: https://www.cepal.org/es/ publicaciones/2812-cohesion-social-inclusion-sentido-pertenencia-america-latina-caribe. Access on: June 2018.

DÁVILA, Paulí; NAYA, Luis. La defensa de los derechos de la infancia en América Latina desde la perspectiva legal: una visión educativa. Educación XX1, Madrid, v. 14, n. 1, p. 201-221, 2011.

DELORS, Jacques. La educación encierra un tesoro. Paris: Ediciones Unesco, 1996.

DUBET, François. La escuela de las oportunidades ¿Qué es una escuela justa? Barcelona: Gedisa, 2005.

ESCUDERO, Juan. Fracaso escolar, exclusión educativa: ¿De qué se excluye y cómo? Profesorado: Revista de Currículum y Formación del Profesorado, v. 1, n. 1, p. 2-24, marzo 2005.

FERNÁNDEZ, Manuel; ALCARAZ, Noelia; SOLA, Miguel. Evaluación y pruebas estandarizadas: una reflexión sobre el sentido, utilidad y efectos de estas pruebas en el campo educativo. Revista Iberoamericana de Evaluación Educativa, Madrid, v. 10, n. 1, p. 51-67, enero 2017.

FONTAINE, Loreto; EYZAGUIRRE, Bárbara. Una estructura que presione a las escuelas a hacerlo bien. Santiago, Chile: CEP, 2001.

GENTILI, Pablo. Marchas y contramarchas: el derecho a la educación y las dinámicas de exclusión incluyente en América Latina. Revista Latinoamericana de Educación, v. 49, n. 1, p. 19-57, jun. 2011.

GODOY, María Paulina; MEZA, María Luisa; SALAZAR, Alida. Antecedentes históricos: presente y futuro de la educación especial en Chile. Santiago: Ministerio de Educación, 2004.

GRAHAM, Linda; SLEE; Roger. An illusiory interiority: interrogating the discourse/s inclusion. Educational Philosophy and Theory, Australia, v. 40, n. 2, p. 277-293, June 2009. 
GRAHAM, Linda; JAHNUKAINEN, Markku. Wherefore art thou, inclusion? Analysing the development of inclusive education in New South Wales, Alberta and Finland. Journal of Education Policy, Londres, v. 26, n. 2, p. 263-288, Apr. 2011.

HIMMEL, Erika; MALTES, Sergio; MAJLUF, Nicolás; GAZMURI, Pedro; ARANCIBIA, Violeta. Análisis de la influencia de factores alterables del proceso educativo sobre la efectividad escolar. Santiago: Editorial Universidad Católica de Chile, 1984.

INFANTE, Marta; MATUS, Claudia; VIZCARRA, Ruby. Razonando sobre la idea de diferencia en las políticas educativas chilenas. Universum, Talca, v. 26, n. 2, p. 143-163, 2011. Availabe at: https://scielo.conicyt.cl/pdf/ universum/v26n2/art_08.pdf. Access on: May 2018.

INZUNZA, Jorge. La construcción del derecho a la educación y la institucionalidad educativa en Chile. Santiago: Ediciones Salesianos, 2015.

LEIVA, María Verónica; ASTORGA, Diego. Condiciones del desarrollo institucional en los centros escolares de Chile. Revista Electrónica de Investigación Educativa, Baja California, v. 16, n. 2, p. 33-51, Sept. 2014.

LÓPEZ, Verónica; JULIO, Cristina; MORALES, Macarena; ROJAS, Carolina; PÉREZ, María Victoria. Barreras culturales para la inclusión: políticas y prácticas de integración en Chile. Revista de Educación, Madrid, v. 363, p. 256-281, dic. 2014 .

LÓPEZ, Verónica; GONZÁLEZ, Pablo; MANGHI, Dominique; ASCORRA, Paula; OYANEDEL, Juan Carlos; REDÓN, Silvia; LEAL, Francisco; SALGADO, Mauricio. Políticas de inclusión educativa en Chile: tres nudos críticos. Archivos Analiticos de Políticas Educativas, Arizona, v. 26, n. 157, p. 96-129, dic. 2018. Availabe at: https://epaa.asu.edu/ojs/article/view/3088 . Access on: Dec. 2018.

MORENO-DOÑA, Alberto; GAMBOA Rodrigo. Dictadura chilena y sistema escolar: a otros dieron de verdades a cosa llamada educación. Educar em Revista, Curitiba, n. 51, p. 51-66, sept. 2014. http://www.scielo. br/scielo.php?script=sci_arttext\&pid=S0104-40602014000100005\&lng=en\&nrm=iso Access on: Mar. 2018.

NEF, Jorge. El concepto de Estado subsidiario y la educación como bien de mercado: un bosquejo de análisis político. Revista Enfoques Educacionales, Santiago, v. 2, n. 2, p. 15-21, enero 2002.

OLIVA, María Angélica. Política educativa chilena 1965-2009. ¿Qué oculta esa trama? Revista Brasileira de Educação, Rio de Janeiro, v. 15, n. 44, p. 311-328. 2010.

OPAZO, Catalina. Educación inclusiva y pedagogía en contextos de desventaja socio-educativa, 2012. Availabe at: http://educacion.flacso.org.ar/files/webform/eventos/ponencia\%20C_Opazo.pdf.pdf. Access on: May 2018.

ORGANIZAÇÃO PARA A COOPERAÇÃO E DESENVOLVIMENTO ECONÔMICO - OCDE. Revisión de políticas nacionales de educación en Chile. Chile: OCDE, 2004.

ORGANIZAÇÃO PARA A COOPERAÇÃO E DESENVOLVIMENTO ECONÔMICO - OCDE. Equidad y calidad de la educación: apoyo a estudiantes y escuelas en desventaja. Francia: OCDE, 2012.

PARDO, Marcela; ADLERSTEIN, Cynthia. Informe Nacional sobre Docentes para la Educación de la Primera Infancia: Chile. Proyecto Estrategia Regional Docente. Santiago: OREALC-Unesco. 2015.

PLÁ, Sebastián. Debates contemporáneos sobre la inequidad y la exclusión educativa en América latina. Sinéctica: Revista Electrónica de Educación, Jalisco, v. 44, p. 1-19, enero/jun. 2015.

RIBEIRO, Raquel. Patologización de la infancia cotidiana. Teoría y Crítica de la Psicología, v. 5, p. 148-156, 2015. Availabe at: http://www.teocripsi.com/ojs/index.php/TCP/article/view/17. Access on: Apr. 2018.

RÍOS, Rafael. Escuela Nueva y saber pedagógico en Colombia: apropiación, modernidad y métodos de enseñanza. Primera mitad del siglo XIX. Historia y Sociedad, n. 24, p. 79-107, 2012.

ROJAS FLORES, Jorge. Historia de la infancia en el Chile republicano, 1810-2010. Santiago: JUNJI, 2010.

ROMÁN, Marcela. Factores asociados al abandono y la deserción escolar en América Latina: una mirada en conjunto. REICE: Revista Iberoamericana sobre Calidad, Eficacia y Cambio en Educación, v. 11, n. 2, p. 33-59, 2013. 
SISTO, Vicente. Inclusión “a la Chilena”: la inclusión escolar en un contexto de políticas neoliberales avanzadas. Archivos Analíticos de Políticas Educativas, Arizona, v. 27, n. 23, p. 1-20, 2019. Availabe at: https://epaa.asu.edu/ojs/article/view/3044. Access on: May 2019.

SKLIAR, Carlos. La educación (que) es del otro: argumentos y desierto de argumentos pedagógicos. Argentina: Novedades Educativas, 2007.

SLEE, Roger. La escuela extraordinaria. España: Morata, 2012.

SLEE, Roger. How do we make inclusive education happen when exclusion is a political predisposition? International Journal of Inclusive Education, v. 17, n. 8, p. 895-907, Dec. 2013.

SLEE, Roger; ALLAN, Julie. Excluding the Included: a recognition of inclusive education. International Studies in Sociology of Education, Londres, v. 11, n. 2, p. 173-191, 2001.

SOTOMAYOR, Carmen; DUPRIEZ, Vincent. Desarrollar competencias docentes en la escuela: aprendizajes de una experiencia chilena de asesoría a escuelas de alta vulnerabilidad social y educativa. Les Cahiers de Recherche en Éducation et Formation, v. 61, n. 1, ago. 2007.

TERIGI, Flavia. El fracaso escolar desde la perspectiva psicoeducativa: hacia una reconceptualización situacional. Revista Iberoamericana de Educación, v. 50, p. 23-39, 2009.

UNITED NATIONS EDUCATIONAL, SCIENTIFIC AND CULTURAL ORGANIZATION - UNESCO. Declaración Mundial sobre Educación para Todos. Jontiem: Unesco, 1990.

UNITED NATIONS EDUCATIONAL, SCIENTIFIC AND CULTURAL ORGANIZATION - UNESCO. Declaración de Salamanca y Marco de Acción para las Necesidades Educativas Especiales. España: Unesco, 1994.

UNITED NATIONS EDUCATIONAL, SCIENTIFIC AND CULTURAL ORGANIZATION - UNESCO. Marco de Acción. Dakar: Unesco, 2000

UNITED NATIONS EDUCATIONAL, SCIENTIFIC AND CULTURAL ORGANIZATION - UNESCO. Cada escuela es un mundo, un mundo de diversidad. Santiago: Unesco, 2003.

UNITED NATIONS EDUCATIONAL, SCIENTIFIC AND CULTURAL ORGANIZATION - UNESCO. Convención sobre los derechos de las personas con discapacidad, 2006. Available at: http://www.un.org/spanish/disabilities/default. asp?id=497. Access on: Mar. 2018.

UNITED NATIONS EDUCATIONAL, SCIENTIFIC AND CULTURAL ORGANIZATION - UNESCO. Declaración de Incheon: hacia una educación inclusiva y equitativa de calidad y un aprendizaje a lo largo de la vida para todos. Corea del Sur: Unicef, 2015.

VELLUTINO, Frank; FLETCHER, Jack; SNOELING, Margaret; SCANLON, Donna. Specific Reading disability (dislexia): what have we learnd in the past four decades? Journal of Child Psychology and Psychiatry, Oxford, v. 45 , n. 1 , p. $2-40,2004$.

NOTA: Dominique Manghi: article coordination, documentary review, analysis, writing, discussion, final edition; Maria Leonor Conejeros Solar: documentary review, analysis, writing, discussion, final edition; Andrea Bustos Ibarra: documentary review, analysis, writing, discussion; Isabel Aranda Godoy: documentary review, analysis, writing, formal review; Vanessa Vega Córdova: analysis, writing, discussion; Kathiuska Diaz Soto: documentary review, analysis, writing.

\section{HOW TO CITE THIS ARTICLE}

MANGHI, Dominique; CONEJEROS SOLAR, María Leonor; BUSTOS IBARRA, Andrea; ARANDA GODOY, Isabel; VEGA CÓRDOVA, Vanessa; DIAZ SOTO, Kathiuska. Understanding Inclusive Education in Chile: An Overview of Policy and Educational Research. Cadernos de Pesquisa, São Paulo, v. 50, n. 175, p. 114-134, Jan./Mar. 2020. https://doi.org/10.1590/198053146605 
